\title{
Soapwort extract supplementation alters antioxidant status of serum, liver and heart tissues in growing Japanese quails reared under chronic intermittent cold stress
}

\author{
Bestami Dalkilic ${ }^{*}$, Mehtap Ozcelik ${ }^{2}$, Zafer Cambay², Naci Omer Alayunt ${ }^{3}$, Ulku \\ Gulcihan Simsek ${ }^{4}$, Seda Iflazoglu Mutlu ${ }^{5}$, Mehmet Ciftci ${ }^{5}$
}

${ }^{1}$ University of Gaziantep, Vocational School of Technical Sciences, Department of Plant and Animal Production, Gaziantep, Turkey

${ }^{2}$ University of Firat, Vocational School of Health Services, Elazig, Turkey

${ }^{3}$ University of Firat, Faculty of Arts and Sciences, Department of Chemistry, Elazig, Turkey

${ }^{4}$ University of Firat, Faculty of Veterinary Medicine, Department of Animal Science, Elazig, Turkey

${ }^{5}$ University of Firat, Faculty of Veterinary Medicine, Department of Animal Nutrition and Nutritional Diseases, Elazig, Turkey

Received February 21, 2016
Accepted May 31, 2017

\begin{abstract}
Antioxidant effect of dietary soapwort extract supplementation was studied in growing Japanese quails suffering from chronic intermittent cold stress. For this purpose, a total of ninety 15 -d-old quails were divided into three groups with three replicates. Chronic intermittent cold stress was applied every night between 22.00 to $06.00 \mathrm{~h}$; starting at $14{ }^{\circ} \mathrm{C}$ for the first week, and gradually weekly lowered to $8^{\circ} \mathrm{C}$. Three groups were fed with corn-soy based standard diets supplemented with 0,50 , and $100 \mathrm{ppm}$ soapwort extract for four weeks. At the end of the study, three males and three females were slaughtered to determine total antioxidant and oxidant status of serum, malondialdehyde, glutathione, glutathione peroxidase activity, superoxide dismutase of liver and heart tissues. Although the dietary soapwort extract had no effect on serum total antioxidant capacity, it significantly lowered the total oxidant status of serum in cold stressed quails. Glutathione and superoxide dismutase enzyme activity of liver and heart tissues were similar among groups. While the dietary soapwort extract had no effect on glutathione peroxidase activity of the heart tissue, it significantly increased glutathione peroxidase activity in the liver tissue. In relation to the control group, malondialdehyde concentrations in the liver and heart tissues were significantly lower in soapwort extract groups. These data suggest that dietary soapwort extract could alleviate the detrimental effects of oxidative stress in growing Japanese quails exposed to cold stress.
\end{abstract}

Malondialdehyde, glutathione peroxidase, saponin, total antioxidant status, total oxidant status

Cold stress in animals shows a suppressive effect on the immune system (Hangalapura 2006). Animals under intense stress suffer from lipid peroxidation of the cell membranes; reactive oxygen species (ROS) such as hydrogen peroxide $\left(\mathrm{H}_{2} \mathrm{O}_{2}\right)$, hydroxyl radical $\left(\mathrm{HO}^{-}\right)$ and superoxide anion radical $\left(\mathrm{O}_{2}^{-}\right)$are formed, resulting in tissue damage (Kovacs 1996). The ROS are made in the mitochondria during normal metabolism and scavenging by cell antioxidant mechanisms such as glutathione (GSH), glutathione peroxidase (GSH-Px) and superoxide dismutase (SOD). However, under cold conditions or any stress conditions, reactive oxygen species are formed much more than the cell scavenging capacity, and so cell damage occurs (Berzinska-Slebodzinska 2001). It is advised that antioxidant and immune system enhancing feed supplements might alleviate the detrimental effects of cold stress (Sahin et al. 2002).

Awareness of potential problems associated with the toxicological and carcinogenic effects of the use of synthetic antioxidant feed preservatives such as butylated hydroxytoluene (BHT) and butylated hydroxyanisole (BHA) has focused research efforts on identifying 
natural alternatives for oxidation control (Kahl and Kappus 1993). Recently, research has focused on identification of plants with natural antioxidant activity. Among these plant compounds are saponins which have several beneficial effects such as antibacterial (Nabinejad 2013), anticarcinogenic (Xiao et al. 2009), hypocholesterolaemic, antiinflammatory, and antioxidant activities (Kucukkurt et al. 2011; Aslan et al. 2005). $\mathrm{Yu}$ et al. (2015) determined antioxidant effects of ginseng stem-leaf saponins with enhancing antioxidant systems and decreasing malondialdehyde concentrations of some lymphoid organs (bursa, spleen, and thymus) in chickens suffering from oxidative stress by intramuscular cyclophosphamide injection.

Gypsophila spp. is a perennial plant (Caryophyllaceae family), called "soapwort" ("coven" in Turkish) as it contains triterpenoid saponins. The root is often used in making the Turkish halvah, for fixing the oils in the mixture or to form a unique texture of halvah with its foaming effect (Baytop 1984).

Plant materials are vastly used in animals due to their antioxidant, antimicrobial, and carminative properties for activating the body's defense systems against detrimental effects of stressful conditions. The aim of this study was to examine the antioxidant activity of soapwort extract in chronic intermittent cold stressed Japanese quails at a growing age.

\section{Materials and Methods}

The Institutional Animal Care and Use Committee procedures were approved by the local Ethics Committee of Firat University (FUHADEK number: 2015/07). A total of ninety 15-day-old Japanese quails (Coturnix coturnix Japonica) were divided into three experimental groups of 30 birds, each group including 10 male and 20 female quails with three replicates. The soapwort extract used in this study was in a powder form (BIOSAP40X, containing more than $40 \%$ triterpenoid saponins), and was provided by Biosaponeks Biotechnology R\&D Ltd (Adana, Turkey). In the experiment, the presence and concentrations of the soapwort extract (SE) in diets were the main factors tested. One group was fed with standard diet (control group) and for the treatment groups, 50 (SE-50 group) and $100 \mathrm{ppm}$ (SE-100 group) of soapwort extract were supplemented to the standard diets. The chemical composition of the soapwort extract used in the study is shown in Table 1. Corn-soy based basal

Table 1. The chemical composition of the soapwort extract, (BIOSAP-40X).

\begin{tabular}{lc}
\hline Analysis & Results, \% \\
\hline Dry matter & 90.73 \\
Crude protein & 2.23 \\
Ether extract & 1.22 \\
Crude cellulose & 0.83 \\
Ash & 6.10 \\
Carbohydrates & 36.35 \\
Saponin & 44.00 \\
\hline
\end{tabular}
kept under standard laying cages with 10 birds per cage under the same environmental conditions. Every night, room temperature was gradually lowered to obtain chronic intermittently cold stress as given in Table 3 . For the sake of the animals' welfare, the temperature was lowered gradually because of the shocking effect of sudden hypothermia on young chicks. The experiment was continued for four weeks and ended when chicks were 43 days old.

At the end of the study, three females and three males were randomly selected in each group and slaughtered by cutting the neck, and blood samples were collected during the slaughter process. Blood samples were immediately centrifuged at 2,500 $\times \mathrm{g}$ for $5 \mathrm{~min}$, and sera were collected. Liver and heart samples were then taken and kept at $-20^{\circ} \mathrm{C}$ until laboratory analyses.

The total oxidant status (TOS) and the total antioxidant status (TAS) of serum samples were measured colorimetrically using a plate reader (ADVIA 2400, Siemens). The TOS was measured at a $540 \mathrm{~nm}$ wavelength using the TOS kit (ASSAY KIT, Catalogue number: RL0024 LOT: RL026, Rel assay diagnostics, Gaziantep, Turkey) and expressed in $\mathrm{mmol}_{2} \mathrm{O}_{2}$ equivalent/l. The TAS was measured at a $660 \mathrm{~nm}$ wavelength using the TAS 
Table 2. Ingredients and chemical composition of the standard diet $(\mathrm{g} / \mathrm{kg})$.

\begin{tabular}{lclc}
\hline Feed ingredients & $\mathrm{g} / \mathrm{kg}$ & Chemical composition & $\mathrm{g} / \mathrm{kg}$ \\
\hline Maize & 410.0 & Dry matter & 894.1 \\
Wheat & 90.0 & Crude protein & 241.0 \\
Soybean meal $(48 \% \mathrm{CP})$ & 290.0 & Ether extract & 63.0 \\
Corn gluten $(43 \% \mathrm{CP})$ & 115.0 & Crude fiber & 33.8 \\
Vegetable oil & 40.0 & Crude ash & 62.5 \\
Dicalcium phosphate & 29.10 & Sugar & 50.0 \\
Limestone & 10.0 & Starch & 342.0 \\
Salt & 3.0 & Calcium** & 10.0 \\
Sodium bicarbonate & 1.0 & Available phosphorus** & 7.3 \\
DL-Methionine & 3.4 & Sodium** & 1.80 \\
L-Lysine & 3.3 & Methionine + cystine** & 10.9 \\
L-Threonine & 0.9 & Lysine** & 14.1 \\
L-Tryptophane & 0.9 & Threonine** & 9.6 \\
Vitamin-mineral premix $*$ & 3.4 & Tryptophan** & 3.7 \\
Total & 1000.0 & Metabolisable energy, $\mathrm{kcal} / \mathrm{kg}^{* * *}$ & 3127 \\
\hline
\end{tabular}

* Provided per kg of diet: retinol, $2.64 \mathrm{mg}$; cholecalciferol,0.04 mg; dl-a-tocopherol-acetate, $11 \mathrm{mg}$; riboflavin, $9.0 \mathrm{mg}$; pantothenic acid, $11.0 \mathrm{mg}$; vitamin B12, $0.013 \mathrm{mg}$; niacin, $26 \mathrm{mg}$; choline, $900 \mathrm{mg}$; vitamin $\mathrm{K}, 1.5 \mathrm{mg}$; folic acid, $1.5 \mathrm{mg}$; biotin, $0.25 \mathrm{mg}$; iron, $30 \mathrm{mg}$; zinc, $40 \mathrm{mg}$; manganese, $60 \mathrm{mg}$; copper, $8 \mathrm{mg}$; selenium, $0.2 \mathrm{mg}$. **: Calculated

***: Calculated, metabolisable energy $(\mathrm{kcal} / \mathrm{kg})=53+38 \mathrm{~B}$ used formula. $\mathrm{B}=(\%$ crude protein $)+(2.25)(\%$ ether extract $)+(1.1)(\%$ starch $)+(\%$ sugar $)$

Table 3. Temperature of the room, ${ }^{\circ} \mathrm{C}$.

\begin{tabular}{lcc}
\hline \multirow{2}{*}{ Days } & \multicolumn{2}{c}{ Times of Day } \\
\cline { 2 - 3 } & From $22.00 \mathrm{~h}$ to $06.00 \mathrm{~h}$ & From $06.00 \mathrm{~h}$ to $22.00 \mathrm{~h}$ \\
\hline $15-22$ & 14 & 26 \\
$22-29$ & 12 & 24 \\
$29-36$ & 10 & 22 \\
$36-43$ & 8 & 22 \\
\hline
\end{tabular}

kit (ASSAY KIT, Catalog number: RL0017 LOT: RL024). The TAS values were expressed as mmol Trolox equiv/l.

Malondialdehyde (MDA) concentrations in the liver and heart tissues were determined spectrophotometrically by the procedures described by Placer et al. (1966). Superoxide dismutase (SOD) activity in the liver and heart tissues was analysed with xanthine and xanthine oxidases to form superoxide radicals which react with nitroblue-tetrazolium using the methods described by Sun et al. (1988). For glutathione peroxidase (GSH-Px) activity of liver and heart tissues, Lawrence and Burk's (1976) procedures were applied. The glutathione (GSH) content of the liver and heart was assayed at $412 \mathrm{~nm}$ by the method of Sedlak and Lindsay (1968). Tissue protein contents were determined by the methods of Lowry et al (1951).

All data were analysed by analysis of variance procedures and significant differences were further subjected to Duncan's multiple range tests by using Statistical Package for the Social Sciences for Windows (2002). The results were considered significant when $P<0.05, P<0.01$, and $P<0.001$.

\section{Results}

Soapwort extract supplementation had no effect on the TAS $(P>0.05)$ while it significantly lowered the TOS $(P<0.001)$ of quails exposed to chronic intermittent cold stress, as shown in Table 4. No significant difference was found between SE-50 or SE100 groups in spite of the numerical difference $(P>0.05)$. Similarly, in vivo antioxidant 
Table 4. The effect of soapwort extract supplementation on total antioxidant and total oxidant status of serum in quails reared under chronic intermittent cold stress.

\begin{tabular}{lcccc}
\hline \multirow{2}{*}{ Traits } & \multirow{2}{*}{ Control } & \multicolumn{3}{c}{ Soapwort extract, ppm } \\
\cline { 3 - 5 } & & SE-50 & SE-100 & $P$ \\
\hline TAS (mmol/1) & $1.07 \pm 0.13$ & $1.08 \pm 0.13$ & $1.12 \pm 0.05$ & NS \\
TOS (mmol/l) & $32.58 \pm 3.37^{\mathrm{a}}$ & $20.04 \pm 1.04^{\mathrm{b}}$ & $16.11 \pm 0.92^{\mathrm{b}}$ & $* * *$ \\
\hline
\end{tabular}

SE-50: $50 \mathrm{ppm}$ soapwort extract added group; SE-100: $100 \mathrm{ppm}$ soapwort extract added group, TAS: Total antioxidant status, TOS: Total oxidant status

$P$ : significance, NS: non-significant,

*** $P<0.001$, a,b Mean values with different superscripts within a row differ significantly

activity was also observed in the heart and liver tissue as given in Table 5. Soapwort extract supplementation significantly decreased MDA concentrations in the liver $(P<0.001)$ and heart $(P<0.01)$ tissues and significantly increased the glutathione peroxidase enzyme activity of the liver $(P<0.05)$ in a dose-dependent manner. Supplementation with either 50 or 100 ppm soapwort extract had no significant effect on the GSH level and SOD activity of the liver and heart tissues $(P>0.05)$.

Table 5. Effect of soapwort extract supplementation on antioxidant status of liver and heart in quails reared under chronic intermittent cold stress

\begin{tabular}{|c|c|c|c|c|c|}
\hline \multirow[b]{2}{*}{ Traits } & \multirow[b]{2}{*}{ Control } & \multicolumn{2}{|c|}{ Soapwort extract, ppm } & \multirow[b]{2}{*}{ SEM } & \multirow[b]{2}{*}{$P$} \\
\hline & & SE-50 & SE-100 & & \\
\hline \multicolumn{6}{|c|}{ MDA (nmol / g prot) } \\
\hline Liver & $9.75^{\mathrm{a}}$ & $7.85^{\mathrm{b}}$ & $5.29^{\mathrm{b}}$ & 0.51 & $* * *$ \\
\hline Heart & $6.03^{\mathrm{a}}$ & $5.52^{\mathrm{ab}}$ & $3.40^{\mathrm{b}}$ & 0.34 & $* *$ \\
\hline \multicolumn{6}{|c|}{ GSH (nmol / g prot) } \\
\hline Liver & 0.13 & 0.13 & 0.13 & 0.01 & NS \\
\hline Heart & 0.25 & 0.25 & 0.24 & 0.01 & NS \\
\hline \multicolumn{6}{|c|}{ GSH-Px ( $\mu$ kat / g prot $)$} \\
\hline Liver & $2.167 .10^{-3 b}$ & $2.5 \cdot 10^{-3 a b}$ & $2.83 .10^{-3 a}$ & 0.01 & * \\
\hline Heart & $3.33 .10^{-3}$ & $3.5 \cdot 10^{-3}$ & $3.33 .10^{-3}$ & 0.01 & NS \\
\hline \multicolumn{6}{|c|}{ SOD $(\mu$ kat / g prot $)$} \\
\hline Liver & 0.617 & 0.6312 & 0.627 & 1.63 & NS \\
\hline Heart & 1.377 & 1.4287 & 1.4055 & 2.26 & NS \\
\hline
\end{tabular}

SE-50: $50 \mathrm{ppm}$ soapwort extract added group; SE-100: $100 \mathrm{ppm}$ soapwort extract added group; MDA: Malondialdehyde; GSH: Glutatione; GSH-Px: Glutathione peroxidase; SOD: Superoxide dismutase

$P$ : Significance, SEM: standard error of the mean, NS: No significant,

*: $P<0.05,{ }^{* *}: P<0.01,{ }^{* * *}: P<0.001,{ }^{\mathrm{a}, \mathrm{b}}$ : Mean values with different superscripts within a row differ significantly

\section{Discussion}

Oxidative stress can be estimated by measuring the decrease in the total antioxidant status (TAS), or more often, by determining the by-products of oxidative damage to cells, lipids, and protein (Bartosz 2003). Additionally, this determination may contribute to the oxidative stress status (Placer et al. 1966; Sedlak and Lindsay 1968). However, a 
new and practical approach can be used to the total oxidant status (TOS) in a sample that provides the certain information about the oxidative damage (Erel 2005).

In this study, antioxidant activity of soapwort extract was observed in Japanese quails exposed to chronic intermittent cold stress. Although no significant effect was observed on the TAS of serum taken at the end of the study, supplementation with soapwort extract significantly affected the TOS of serum compared to control by $38 \%$ and $50 \%$ lower in SE50 and SE-100 groups, respectively. Furthermore, MDA concentrations of heart and liver tissues were lowered by the soapwort extract supplementation in this study. MDA which is an intrinsic consequence of oxidative stress resulting from lipid peroxidation is a useful marker of oxidative damage level. Parallel to this, the MDA concentration in the liver in our study was found by $20 \%$ and $46 \%$ lower in SE-50 and SE-100 groups than in control group, respectively. Furthermore, among SE groups, the MDA concentrations in the liver were found by 33\% lower in SE-100 group than SE-50 group. Similarly, for the heart tissue the MDA concentration in SE-50 and SE-100 groups was found lower by $25 \%$ and $44 \%$, respectively, compared to the control group. Also, among the SE groups the MDA concentration was $25 \%$ lower in group SE-100 compared to group SE-50. Apparently, soapwort extract supplementation considerably prevented lipid peroxidation in cold stress. With regard to the antioxidant enzyme activity, a significant increase due to soapwort extract supplementation was found only for the liver GSH-Px activity.

Previous studies of the antioxidant activity of saponin-rich plants support our results. Arslan and Celik (2013) proved the in vitro antioxidant activity of soapwort saponins in a recent study. The authors studied the in vitro antioxidant capability of the saponinrich fraction of the roots of plants Gypsophila arrostii, G. pilulifera, and G. simonii (Caryophyllaceae family) naturally found in Turkey, by two methods of free-radical scavenging activity using 2,2-diphenyl-1-picryl hydrazyl (DPPH) and ABTS assay. Kucukkurt et al. (2011) conducted a study in rats exposed to X-radiation and found that saponin contained in Agrostemma githago L. and Saponaria officinalis L. extracts enhanced the antioxidant systems and decreased the incidence of lipid peroxidation in blood samples. Sur et al. (2001) investigated the antioxidant mechanism of tea saponins occurring by xanthine and xanthine oxidase pathway in rats. Parallel to these findings, the soapwort extract reduced oxidant levels of serum and MDA concentrations in the liver and heart in our study. Another study conducted on alloxan-induced diabetic rats by Alli Smith and Adanlawo (2014) reported that saponin extract treatment from the root of Garcinia kola significantly decreased the MDA concentration in the liver, kidney and heart tissues of rats exposed to alloxan. Also, saponin contained in the Yucca schidigera extract was found to alleviate the lipid peroxidation due to irradiation in rabbits exposed to gamma radiation for a period of 4 weeks (Enginar et al. 2006). Fidan and Dundar (2008) conducted a study to determine the effects of diet supplementation with saponin-containing Yucca schidigera (Sarsaponin 30, Desert King International, San Diego, CA, USA), Quillaja saponaria (Nutrafito, Desert King International, San Diego, CA, USA), and their mixture powder (Nutrafito plus, Desert King International, San Diego, CA, USA) on deoxyribonucleic acid damage, protein oxidation, and lipid peroxidation in experimentally streptozotocin-induced diabetic rats. The researchers found that TAS was not affected by supplements which is supported by our results. Also similarly to our results, the MDA concentrations of plasma were found significantly lower in supplemented groups. They concluded that both plants have antioxidant activity. Another study carried out by Kucukkurt et al. (2008) reported that 100 and $200 \mathrm{ppm}$ Yucca schidigera (Sarsaponin 30) supplemented to rats diet significantly lowered blood and kidney MDA levels with no effect on GSH concentrations.

In conclusion, this research demonstrated that saponin-rich soapwort extract has 
antioxidant and free radical scavenging ability and could be used as a natural antioxidant supplement (especially at $100 \mathrm{ppm}$ ) in preventing or slowing the detrimental effects of cold or any associated oxidative stress.

\section{Acknowledgement}

The authors thank the Biosaponeks Biotechnology Industry and Trade Limited Company, Adana Turkey for providing the soapwort extract.

\section{Conflict of interest}

There is no commercial relationship between all the authors and the company (Biosaponeks Biotechnology Industry and Trade Limited Company, Adana Turkey).

\section{References}

Alli Smith YR, Adanlawo IG 2014: In vitro and in vivo antioxidant activity of saponin extracted from the root of Garcinia kola (Bitter kola) on alloxan-induced diabetic rats. WJPPS 3: 8-26

AOAC 2000: Official Methods of Analysis Association of AOAC International. $17^{\text {th }}$ edn, (AOAC International Maryland)

Arslan I, Celik A 2013: Saponin Rich Fractions (SRPs) from Soapwort Show Antioxidant and Hemolytic Activity. APCBEE Procedia 7: 103-108

Aslan R, Dundar Y, Eryavuz A, Bulbul A, Kuçukkurt I, Fidan AF, Akinci Z 2005: Effects of various quantities of Yucca schidigera powder (Deodorase) added to diets on the performance, some hematological and biochemical blood parameters, and total antioxidant capacity of laying hens. Rev Med Vet 156: $350-355$

Bartosz G 2003: Total antioxidant capacity. Adv Clin Chem 37: 219-292

Baytop T 1984: Treatment with plants in Turkey (In the past and today) (In Turkish). Istanbul University Publications, Number: 3255, Istanbul, Turkey, pp 520

Berzinska-Slebodzinska E 2001: Fever induced oxidative stress: the effect of thyroid status and the 5'-monodeiodinase activity, protective role of selenium and vitamin E. J Phys Pharmacology 52: 275-284

Carpenter KJ, Clegg KM 1956: The metabolizable energy of poultry feeding stuffs in relation to their chemical composition. J Sci Food Agric7: 45-51

Crampton EW, Maynard LA 1983: The relation of cellulose and lignin content to nutritive value of animal feeds. J Nutr 15: 383-395

Enginar H, Avci G, Eryavuz A, Kaya E, Kucukkurt I, Fidan AF 2006: Effect of Y. schidigera extract on lipid peroxidation and antioxidant activity in rabbits expose gamma radiation. Rev Med Vet 157: 415-419

Erel O 2005: A new automated colorimetric method for measuring total oxidant status. Clin Biochem 38 : 1103-1111

Fidan AF, Dundar Y 2008: The effects of Yucca schidigera and Quillaja saponaria on DNA damage, protein oxidation, lipid peroxidation, and some biochemical parameters in streptozotocin-induced diabetic rats. J Diab Comp 22: 348-356

Hangalapura BN, Kaiser MG, Poel JJ, Parmentier HK, Lamont SJ 2006: Cold stress equally enhances in vivo pro-inflammatory cytokine gene expression in chicken lines divergently selected for antibody responses. Devel Comp Immunol 30: 503-511

Kahl R, Kappus H 1993: Toxicology of the synthetic antioxidants BHA and BHT in comparison with the natural antioxidant vitamin E. Z Lebensm Unters Forsch 196: 329-338

Kovacs P, Juranek I, Stankovicova T, Svec P 1996: Lipid peroxidation during acute stress. Pharmazie 51: 51-53

Kucukkurt I, Ince S, Enginar H, Eryavuz A, Fidan AF, Kargioglu M 2011: Protective effects of Agrostemma githago L. and Saponaria officinalis L. extracts against ionizing radiation-induced oxidative damage in rats. Rev Med Vet 162: 289-296

Kucukkurt I, Ince S, Fidan AF, Ozdemir A 2008: The effects of dietary supplementation of different amount of Yucca schidigera powder (Sarsaponin $30^{\circledR}$ ) on blood and tissue antioxidant defense systems and lipid peroxidation in rats. J Anim Vet Adv 7: 1413-1417

Lalitha T, Seshadri R, Venkataraman LV 1987: Isolation and properties of saponins from Madhuca butyracea seeds. J Agric Food Chem 35: 744-748

Lane JH, Eynon L 1923: Determination of reducing sugars by means of Fehling's solution with methylene blue as internal indicator. J Soc Chem Ind Trans 42: 32-36

Lawrence RA, Burk RF 1976: Glutathione peroxidase activity in selenium-deficient rat liver. Bioch Bioph Res Comm 71: 952-958

Lowry OH, Rosebroughv NJ, Farr AL, Randall RJ 1951: Protein measurement with the Folin phenol reagent. J Biol Chem 193: 265-275

Nabinejad A 2013: Antibacterial effects of Saponaria officinalis extracts against avian pathogenic Escherichia coli (APEC). Afr J Agr Res 8: 2068-2071 
NRC 1994: Nutrient Requirements of Poultry, $9^{\text {th }}$ edn. Washington, DC, National Academic Press

Placer AZ, Linda LC, Johnson B 1966: Estimation of product of lipid peroxidation (malonyldialdehyde) in biochemical systems. Anal Biochem 16: 359-364

Sahin K, Sahin N, Kucuk O 2002: Effects of dietary chromium and ascorbic acid supplementation on digestion of nutrients, serum antioxidant status and mineral concentrations in laying hens reared at a low ambient temperature. Biol Trace Element Res 87: 113-124

Sedlak J, Lindsay RHC 1968: Estimation of total protein bound and non-protein sulfhydryl groups in tissue with Ellmann's reagent. Anal Biochem 25: 192-205

SPSS Inc 2002: SPSS for Windows Release 11.5 (6 September 2002), Standard Version, Copyright SPSS Inc., Chicago

Sun Y, Oberley LW, Li Y 1988: A simple method for clinical assay of superoxide dismutase. Clin Chem 34: 497-500

Sur P, Chaudhuri T, Vedasiromoni JR, Gomes A,Ganguly DK 2001: Antiinflammatory and antioxidant property of saponins of tea. Biol Pharm Bull 24: 209-213

Xiao X, Bai P, Bui Nguyen TM, Xiao J, Liu S, Yang G, Hu L, Chen X, Zhang X, Liu J, Wang H 2009: The antitumoral effect of Paris Saponin I associated with the induction of apoptosis through the mitochondrial pathway. Mol Cancer Ther 8: 1179-1188

Yu J, Chen Y, Zhai L, Zhang L, Xu Y, Wang S, Hu S 2015:Antioxidative effect of ginseng stem-leaf saponins on oxidative stress induced by cyclophosphamide in chickens. Poult Sci 94: 927-933 